\title{
Specific Activities and Annual Effective Dose of Natural Radionuclides Due to the Intake of Some Types of Sugar Available in Baghdad Markets
}

\author{
Basim Khalaf Rejah \\ Collage of Science for Women, Baghdad University, Baghdad, Iraq \\ Email address: \\ basimkrphys@csw.uobaghdad.edu.iq \\ To cite this article: \\ Basim Khalaf Rejah. Specific Activities and Annual Effective Dose of Natural Radionuclides Due to the Intake of Some Types of Sugar \\ Available in Baghdad Markets. American Journal of Physics and Applications. Vol. 5, No. 2, 2017, pp. 20-23. \\ doi: 10.11648/j.ajpa.20170502.12
}

Received: February 6, 2017; Accepted: February 18, 2017; Published: March 9, 2017

\begin{abstract}
In this research the specific activity of natural radionuclides ${ }^{226} \mathrm{Ra},{ }^{232} \mathrm{Th}$ and ${ }^{40} \mathrm{~K}$ were determined by sodium iodide enhanced by thallium NaI (Tl) detector and assessed the annual effective dose in Beladi, Aldar, Alusraa, Alkhaleej and Aletehaad which are available in Baghdad markets. The specific activity of ${ }^{40} \mathrm{~K}$ has the greater value in all the types which is in the range of allowed levels globally that suggested by UNSCEAR. The mean value of annual effective doses was $0.198,0.094$ and $0.098 \mathrm{mSv} / \mathrm{y}$ for ${ }^{226} \mathrm{Ra},{ }^{232} \mathrm{Th}$ and ${ }^{40} \mathrm{~K}$ respectively.
\end{abstract}

Keywords: Natural Radionuclides, Sugar, Contamination, Ingestion, Annual Effective Dose

\section{Introduction}

The radiation is a natural phenomenon surrounding human beings everywhere in daily life, and human activity has led to increased concentrations in some locations or due to accidental or certain industrial problems or mismanagement, which lead to cases of serious pollution, radiation during the accidents that occur in nuclear reactors or because of nuclear tests or radioactive waste leaking from the vehicles and satellites or due to serious garbage resulting from factories that use chemicals processing radiocarbon dating, where this radiation returned to earth contaminated air, water, soil and food, leading to fatal and deadly risk to humans and other living organisms, or organisms cause abnormalities or imbalances in the vital systems, according to radiation dose and type of level $[1,2]$. Radioactive contamination is known emission serious radiation as a result of incidents get in nuclear reactors or of radioactive waste or any source used in radiation harmful doses is destroying the organism cells directly upon exposure to radiation or indirectly through its concentration in the air, water or soil or food or sewage sludge [3, 4]. Sources of radioactive contamination and other natural sources include the result of human activities, and includes natural ionizing cosmic rays, X-rays and gamma rays emitted by radioactive rock and potassium [5]. The sources resulting from human activities include radioactive medicines used in the medical fields, radioactive materials used in the biological sciences X-rays, as well as rays of nuclear reactors and nuclear weapons and electronic equipment [6]. The amount of cosmic radiation vary according to place high above sea level and depending on the geographical location, where the least amount in the vicinity of the surface of the sea, places, and increasingly higher you go with him, we find the higher you go with him by ten thousand feet whenever doubled the amount of cosmic rays three times. It should be noted that the atmosphere is a protective barrier of cosmic rays [7,8]. The outer shell of soil containing amounts of radioactive elements such as uranium and thorium, and the concentration of radioactive elements varies depending on the soil type, we find that their focus is getting the granite rocks and the least in the sandy soil. Radiation from the soil mainly composed of gamma radiation, which absorbs the alpha and beta inside the outer shell of the soil [9]. There are some natural radioactive elements such as carbon-14, potassium 40 in human food and in the body. There is also the human body radium 226 and polonium-210 $\mathrm{Ba}$ and $\mathrm{Sr} 90$, and vary the amount not to beam from a member of the last human body, for example, 
increasing the amount of natural radiation in the lung than in bone marrow $[10,11]$. Using X-rays or nuclear in the field of disease diagnosis and treatment, which contain trace elements in the treatment of certain diseases such as thyroid poisoning which uses radioactive iodine treatment. Studies indicate that the use of radioactive drag increasing year after year, so this should drag is considered an important source of human exposure to radiation [12,13]. After the discovery of nuclear fission, the first nuclear reactor built in 1942, and then followed by the Manhattan project to establish the first atomic weapons, so at the end of World War II. I have used nuclear reactors, and is still used to generate power, resulting from the use of these reactors, radiation contamination of the environment, especially the environment surrounding the reactors, and environmental pollution increase significantly because of the incidents of explosion of nuclear reactors, such as the Chernobyl nuclear explosion $[14,15]$.

The aim of current work is measuring specific activity for ${ }^{238} \mathrm{U},{ }^{232} \mathrm{Th}$ and ${ }^{40} \mathrm{~K}$ in samples of sugar; Beladi, Aldar, Alusraa, Alkhaleej and Aletehaad in the local markets of Baghdad city in 2015 and the calculation of the annual effective dose resulting from the presence of these radioactive isotopes using a gamma spectrometry, $\mathrm{NaI}(\mathrm{Tl})$ detector, this work is necessary in the viewpoint radiation protection and the search for the presence of natural radioactive elements in food covered by the humans.

\section{Materials and Experimental}

\subsection{Specific Activity}

The specific activity S. A were calculated by equation [16]:

$$
\text { S. } A=A / M
$$

Where A: The activity that determined directly from screen of the system and

M: The mass of sample.

Samples Beladi, Aldar, Alusraa, Alkhaleej and Aletehaad available in Baghdad markets prepared in $1 \mathrm{~kg}$ for each sample (one sample for any type of sugar). Gamma spectroscopy with Sodium iodide (NaI (Tl)) (3" X 3") detector which are calibrated for a period of 3600 seconds, and completely isolated by lead shield [17] were used to determine NORM concentrations, in milk powdered samples.

The specific activity of radioactive series of uranium 238 and thorium - 232 account that has been indirectly by identifying the radioactivity for their daughters. Because of the $\mathrm{NaI}(\mathrm{Tl})$ detector is characterized by a poor of his efficiency in energy resolution was selected radionuclides daughter to determine the concentration of radioactivity for two series of ${ }^{238} \mathrm{U}$ and ${ }^{232} \mathrm{Th}$ as it was chosen nuclide ${ }^{226} \mathrm{Ra}$ to indicate the radioactivity for a series of ${ }^{238} \mathrm{U}$, which have been determined through radioactive isotope ${ }^{214} \mathrm{~Pb}$, as well as determined a series of ${ }^{232} \mathrm{Th}$ through a radioactive isotope ${ }^{212} \mathrm{~Pb}$, as regard for $40 \mathrm{~K}$ can be clearly detected directly by the detector [17]. One $\mathrm{kg}$ of the sample in the measuring cylinder is placed inside measurement system that is already calibrated for 3600 seconds [17]. Measurement system has been isolated by the shield of lead to reduce background radiation. Activity were determined directly from the system.

\subsection{Radiation Weighting Factor}

The radiation weighting factor is a dimensionless factor used to obtain the equivalent dose from the absorbed dose averaged over a tissue or organ and is based on the type of radiation absorbed. The radiation weighting factor for photons equal to 1 [18].

\subsection{Annual Effective Dose}

The annual effective dose ( $A E D$ in $\mathrm{Sv} / \mathrm{y})$ to the public can be given according to ICRP [19];

$$
A E D\left(S v \cdot y^{-1}\right)=C\left(S v \cdot B q^{-1}\right) X A_{i}\left(B q \cdot y^{-1}\right)
$$

$C$ is the coefficient of dose conversion for ingestion $\left(\mathrm{Sv} \cdot \mathrm{Bq}^{-1}\right)$. The annual intake $\left(A_{i}\right.$ in $\left.\mathrm{Bq} / \mathrm{y}\right)$ from taking consuming $200 \mathrm{gm} /$ day is considered by equation [18];

$$
A_{i}\left(B q \cdot \mathrm{y}^{-1}\right)=S . A\left(B q . \mathrm{kg}^{-1}\right) \times 365 \times \text { consumption of milk }
$$

The coefficient of dose conversion $\mathrm{C}$ were recommended for ${ }^{226} \mathrm{Ra},{ }^{232} \mathrm{Th}$ and ${ }^{40} \mathrm{~K}$ were $2.8 \times 10^{-7}, 2.3 \times 10^{-7}$ and $6.2 \times$ $10^{-9} \mathrm{~Sv} \cdot \mathrm{Bq}^{-1}$ respectively [18]. The annual effective dose due to the intake were calculated by using equation 1 .

\section{Results and Discussion}

Specific activity of uranium-238 series, thorium - 232 and potassium -40 in samples of sugar are listed in Table 1.

Table 1. The specific activity of $U^{238}, T h^{232}$ and $K^{40}$ in Bq/kg in all sugar samples.

\begin{tabular}{llll}
\hline Sample & $\mathbf{U - 2 3 8} \mathbf{~ B q} / \mathbf{k g}$ & $\mathbf{T h}-\mathbf{2 3 2} \mathbf{~ B q} / \mathbf{k g}$ & $\mathbf{K - 4 0 ~ B q} / \mathbf{k g}$ \\
\hline Beladi & 12.28 & 4.69 & 103.68 \\
Aldar & 8.47 & 6.76 & 235.48 \\
Alusraa & 14.46 & 8.17 & 225.58 \\
Alkhaleej & 3.45 & 2.28 & 304.72 \\
Aletehaad & 11.4 & 9.6 & 257 \\
Average & 10.012 & 6.3 & 225.292 \\
\hline
\end{tabular}

From Table: 1, one can see that the average value of specific activity of ${ }^{238} \mathrm{U}$ was $10.012 \mathrm{~Bq} / \mathrm{kg}$, the maximum value was $14.46 \mathrm{~Bq} / \mathrm{kg}$ in Alusraa sample while the minimum value was $3.45 \mathrm{~Bq} / \mathrm{kg}$ in Alkhaleej sample. The mean value of specific activity for ${ }^{232} \mathrm{Th}$ was $6.3 \mathrm{~Bq} / \mathrm{kg}$, the maximum value was $9.6 \mathrm{~Bq} / \mathrm{kg}$ in Aletehaad sample while the minimum value was $2.28 \mathrm{~Bq} / \mathrm{kg}$ in Alkhaleej sample. The mean, maximum and minimum value of specific activity for ${ }^{40} \mathrm{~K}$ was $225.292,304.72$ and $103.68 \mathrm{~Bq} / \mathrm{kg}$ respectively, the maximum and minimum value was appeared in Alkhaleej and Beladi sample respectively. Figures.1, 2 and 3 shows that the specific activities of ${ }^{238} \mathrm{U},{ }^{232} \mathrm{Th}$ and ${ }^{40} \mathrm{~K}$ in the different samples. 


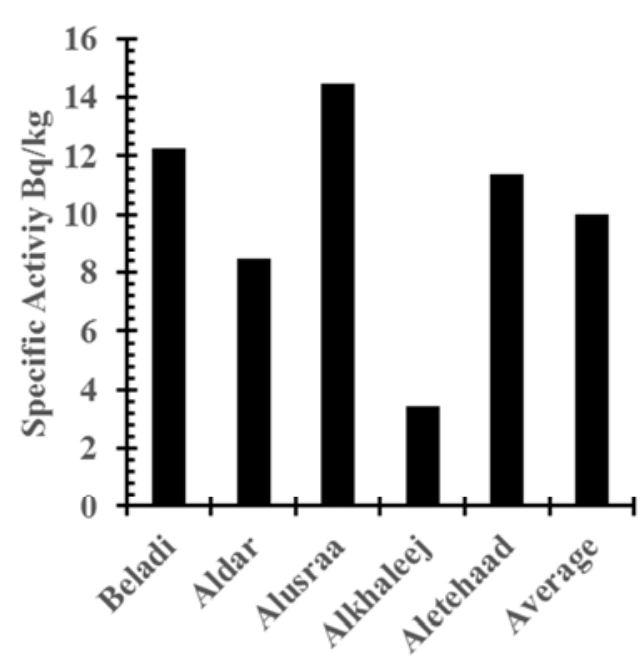

Samples

Figure 1. The specific activity for ${ }^{238} U$ in all samples.

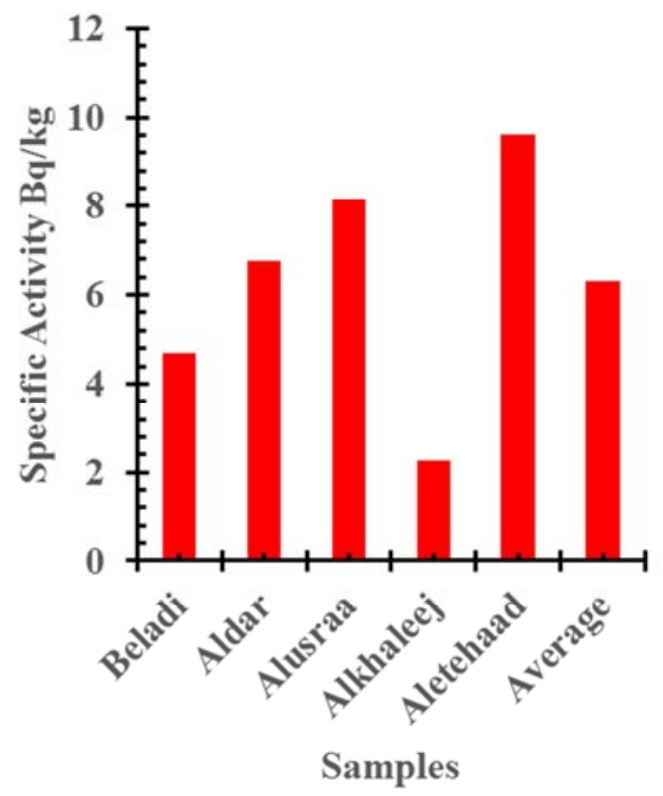

Figure 2. The specific activity for ${ }^{232} \mathrm{Th}$ in all samples.

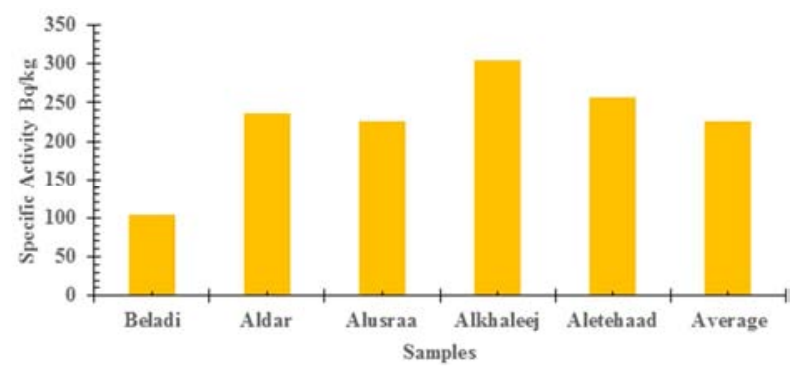

Figure 3. The specific activity for ${ }^{238} U$ in all samples.

The annual effective dose AED in $\mathrm{mSv} / \mathrm{y}$ was calculated by equation 2 and listed in Table 2. From Table 2. the maximum value of annual effective dose for ${ }^{238} \mathrm{U}$ series were $0.3 \mathrm{mSv} / \mathrm{y}$ in Alusraa sample, the minimum value was 0.07 $\mathrm{mSv} / \mathrm{y}$ in Alkhaleej sample while the average value was
$0.198 \mathrm{mSv} / \mathrm{y}$. The average value of annual effective dose for ${ }^{232} \mathrm{Th}$ series and ${ }^{40} \mathrm{~K}$ was 0.094 and $0.098 \mathrm{mSv} / \mathrm{y}$ respectively, the maximum and minimum value was $0.14,0.04,0.14$ and $0.05 \mathrm{mSv} / \mathrm{y}$ in Alusraa, Alkhaleej, Alkhaleej and Beladi powdered milk sample respectively as shown in Figures.4, 5 and 6.

Table 2. The annual effective dose in all sugar samples.

\begin{tabular}{llll}
\hline Sample & $\begin{array}{l}\text { Eff. } \mathbf{m S v} / \mathbf{y} \text { for } \\
\text { U-238 }\end{array}$ & $\begin{array}{l}\text { Eff. } \mathbf{~ m S v} / \mathbf{y} \text { for } \\
\text { Th-232 }\end{array}$ & $\begin{array}{l}\text { Eff. } \mathbf{m S v} / \mathbf{y} \text { for } \\
\text { K-40 }\end{array}$ \\
\hline Beladi & 0.25 & 0.08 & 0.05 \\
Aldar & 0.17 & 0.11 & 0.11 \\
Alusraa & 0.3 & 0.14 & 0.1 \\
Alkhaleej & 0.07 & 0.04 & 0.14 \\
Aletehaad & 0.2 & 0.1 & 0.09 \\
Average & 0.198 & 0.094 & 0.098 \\
\hline
\end{tabular}

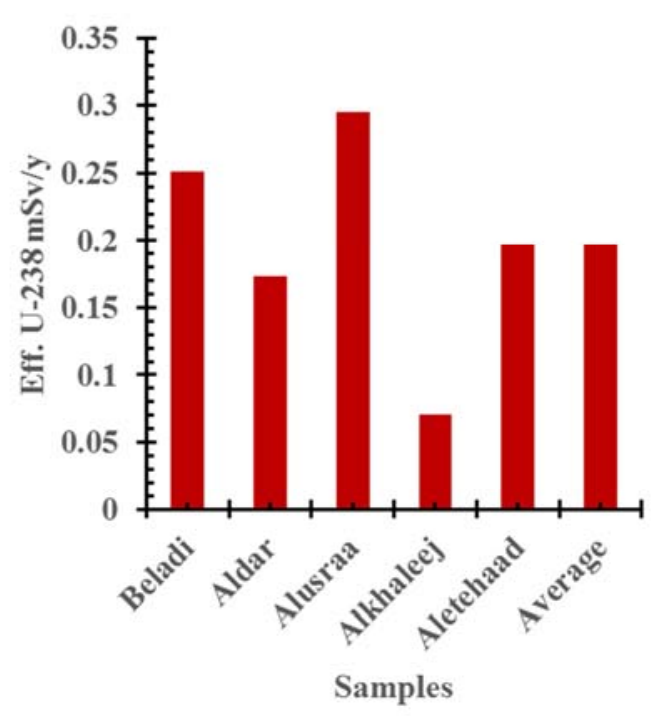

Figure 4. $A E D(m S v / y)$ for ${ }^{238} U$ in all samples.

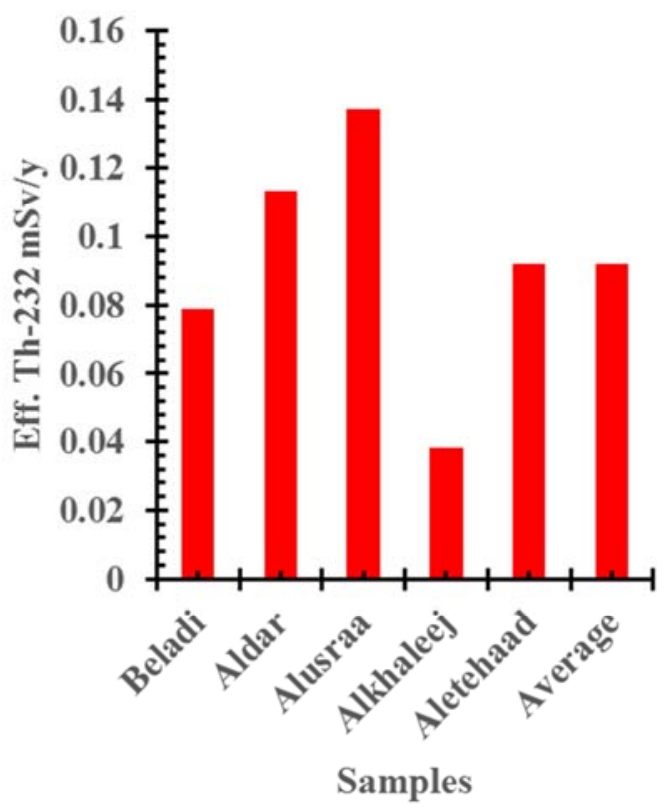

Figure 5. $A E D(m S v / y)$ for ${ }^{232}$ Th in all samples. 


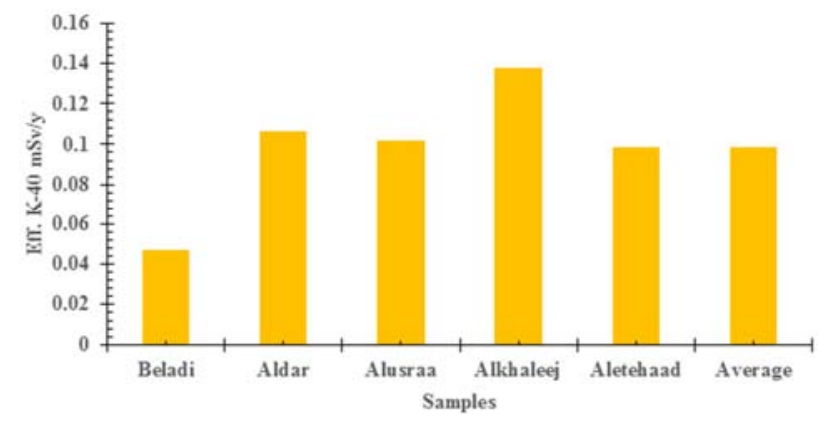

Figure 6. $A E D(m S v / y)$ for ${ }^{40} \mathrm{~K}$ in all samples.

\section{Conclusion}

Specific activity for ${ }^{226} \mathrm{Ra},{ }^{232} \mathrm{Th}$ and ${ }^{40} \mathrm{~K}$ in different samples of sugar was measure by $\mathrm{NaI}(\mathrm{Tl})$ detector. The average value of specific activity for radionuclide ${ }^{40} \mathrm{~K}$ was highest in all samples. The annual effective dose that accumulated from all isotopes was in the allowed levels globally.

\section{References}

[1] Kolesnikov, S., Kazeev, K. and Valjkov, V .(2001) .Bio ecological principles of soil pollution monitoring and regulation. (Rostov-on-Don: CVVR). (in Russian).

[2] Moiseenko, T. (1999). Methodology and methods for determining critical loads (as applied to surface water of the Kola subarctic environment). Izvestiya RAS. Series geographical, 5, 68-78.

[3] Lavrentyeva, G. (2013). Radio ecological analysis of the area of the storage of radioactive waste. Safety in techno sphere, 2 (6), 14-19. (in Russian).

[4] Basim K., (2011), "Measurement of Background Radioactivity in Sewage Sludge for Baghdad City Treatment Stations", Baghdad Science Journal, 8, 2, 439-443.

[5] Demidova, O. A. (2007). Development of methods for assessing ecosystem risks of emission effects from gas industry objects. Dissertation, Research Institute of Natural Gases and Gas Technologies.

[6] Ovchinnikova, I. and Vasiljevskaya, V. (2003). Risk assessment of soil pollution based on a concept of critical loads. Ecological assessment and mapping, 6, 42-49.

[7] ICRP, (1990). Recommendations of the international
Commission on Radiological Protection, Publication 60 (21) 192-201.

[8] ICRP, (2004). Main principles for assessing ionizing radiation effects on living organisms except human body .Publication 91, (Moscow: Komtechprint). (in Russian).

[9] Tzortzis, M., Tsertos, H., Christofides, S. and Christodoulides, G. (2003a). Gamma-ray measurements of naturally occurring radioactive samples from Cyprus characteristic geological rocks. Radiation Measurements, 37, 221-229.

[10] Evseeva, T, Gerasjkin, S. and Belykh, E. (2012). Radioactive risk assessment for reference plant species (common pine and cat pea) from the territory of a radioactive waste storage. Radiation biology. Radioecology ,52 (2), 187-197.

[11] Jeyakumar, T., Kalaiarasi, I., Rajavel, A., Anbu, M. and Kumar, R. (2014). Levels of Organochlorine Pesticide Residues in Water and Sediment from Selected Agricultural Sectors of Kanyakumari District, Tamil Nadu, India. Int. J . Environ. Res., 8, 493-500.

[12] Wan, M. T. (2013). Ecological risk of pesticide residues in the British Columbia environment: 1 973-201 2. Journal of Environmental Science and Health, Part B: Pesticides, Food Contaminants, and Agricultural Wastes, 5, 344-363.

[13] Jeyakumar, T., Kalaiarasi, I., Rajavel, A., Anbu, M. and Kumar, R. (2014). Levels of Organochlorine Pesticide Residues in Water and Sediment from Selected Agricultural Sectors of Kanyakumari District, Tamil Nadu, India. Int. J . Environ. Res., 8, 493-500.

[14] Bozdogan, A. M. (2014). Assessment of total risk on nontarget organisms in fungicide application for agricultural sustainability .Sustainability, 6, 1046-1058.

[15] Lederer C. M.; Shirley V, S.; Browne E.; Dairiki J. M. and Doebler R. E.; (1978). Table of Isotopes, 7th Edition, Inc. John Wiley.

[16] Basim Khalaf Rejah (2015) Natural Occurring Radioactive Materials (NORM) and Technologically Enhanced NORM (TENORM) Measurements on Oil Field in North Region of Iraq. PhD. Thesis, Baghdad University.

[17] International Basic Safety Standard for Protection against Ionizing Radiation and for the Safety of Radiation Sources. (2011) Safety Series No. 115, International Atomic Energy Agency (IAEA), Vienna.

[18] International Commission on Radiological Protection (ICRP) (2013) Age-Dependent Doses to Members of the Public from Intake of Radionuclides: Part 5 Compilations of Ingestion and Inhalation Dose Coefficients (ICRP Publication 72), Pergamon Press; Oxford. 